Research paper

\title{
Polymorphisms of CYP2C8, CYP2C9 and CYP2C19 and risk of coronary heart disease in Russian population
}

\author{
Alexey Polonikov a, b, *, Alexander Kharchenko ${ }^{c}$, Marina Bykanova ${ }^{\mathrm{a}, \mathrm{d}}$, Svetlana Sirotina ${ }^{\mathrm{a}}$, Irina Ponomarenko ${ }^{\mathrm{a}}$, \\ Anna Bocharova ${ }^{e}$, Kseniya Vagaytseva ${ }^{e}$, Vadim Stepanov ${ }^{e}$, Olga Bushueva ${ }^{\text {a, }}$, Mikhail Churnosov ${ }^{\mathrm{f}}$, \\ Maria Solodilova ${ }^{\mathrm{a}}$ \\ a Department of Biology, Medical Genetics and Ecology, Kursk State Medical University, 3 Karl Marx St., Kursk 305041, Russian Federation \\ ${ }^{\mathrm{b}}$ Laboratory of Statistical Genetics and Bioinformatics, Research Institute for Genetic and Molecular Epidemiology, Kursk State Medical University, 18 Yamskaya St., Kursk 305041, Russian \\ Federation \\ ${ }^{\mathrm{c}}$ Department of Internal Medicine, Kursk State Medical University, 14 Pirogova St., Kursk 305035, Russian Federation \\ ${ }^{\mathrm{d}}$ Laboratory of Genomic Research, Research Institute for Genetic and Molecular Epidemiology, Kursk State Medical University, 18 Yamskaya St., Kursk 305041, Russian Federation \\ e Evolutionary Genetics Laboratory, Research Institute of Medical Genetics, Tomsk National Medical Research Center, 10 Nabereznaya Ushaiki, Tomsk 634050, Russian Federation \\ ${ }^{\mathrm{f}}$ Department of Medical Biological Disciplines, Belgorod State University, 85 Pobeda St., Belgorod 308015, Russian Federation
}

\section{A R T I CLE I N F O}

Keywords:

Coronary heart disease

Arachidonic acid metabolism

Epoxyeicosatrienoic acids

Genetic susceptibility

Cytochrome P450

CYP2C subfamily

Single nucleotide polymorphism

\begin{abstract}
A B S T R A C T
Epoxyeicosatrienoic acids (EETs) are important vasoactive products of arachidonic acid metabolism with a wide range of biological actions in the cardiovascular system. The present study investigated whether single nucleotide polymorphisms (SNP) of genes coding cytochrome P450 2C subfamily, enzymes involved in biosynthesis of EETs, are associated with the risk of coronary heart disease (CHD). A total of 1255 unrelated Russian subjects comprising 561 patients with angiographically diagnosed CHD and 694 age- and sex-matched healthy subjects were included in the study. DNA samples from all study participants were genotyped for six common SNPs rs7909236, rs1934953 of CYP2C8, rs9332242, rs4918758 and rs61886769 of CYP2C9 and rs4244285 of CYP2C19 using by the Mass-ARRAY 4 system. SNP rs4918758 of CYP2C9 was associated with decreased risk of CHD (codominant model) at a borderline significance with odds ratio adjusted for sex and age 0.61 (95\% CI: 0.41-0.92, $P=0.038$, $Q=0.20)$. SNP rs9332242 of CYP2C9 showed a trend towards association with increased CHD risk in cigarette smokers $(P=0.049, Q=0.29)$. Log-likelihood ratio test (LRT) pointed out epistatic interactions between rs9332242 and rs61886769 of CYP2C9 (codominant model, $P_{\text {interaction }}=0.02$ ), however, this $P$-value did not survive after correction for multiple tests. Bioinformatic analysis revealed a regulatory potential for a majority of the investigated SNPs. Our preliminary results demonstrate that polymorphisms of genes encoding CYP2C subfamily represent potential genetic markers of CHD susceptibility. Further studies are required to substantiate the contribution of these genes to the disease risk.
\end{abstract}

\section{Introduction}

Coronary heart disease (CHD) is a common cardiovascular disorder (CVD), a leading cause of mortality and disability worldwide (Roger et al., 2012). CHD is the primary cause of death in the Russian Federation, accounting for $45.3 \%$ of total CVD direct health care costs $(\sim \$ 3.1$ billion) in the country (Notzon et al., 1998; Kontsevaya et al., 2013).
Coronary heart disease is thought to be complex multifactorial disorder resulting from the interaction between multiple genetic and environmental factors (Poulter, 1999; Arnett et al., 2007). Genome-wide association studies have identified a number of genes related with CHD susceptibility in different populations of the world and provided insights into the molecular basis of the disease (Nikpay et al., 2015; McPherson and Tybjaerg-Hansen, 2016). However, the effect sizes of the identified loci responsible for CHD susceptibility were for the most part modest

Abbreviations: AA, arachidonic acid; CHD, coronary heart disease; CI, confidence intervals; CVD, cardiovascular disorder; EETs, epoxyeicosatrienoic acids; FDR, false discovery rate;

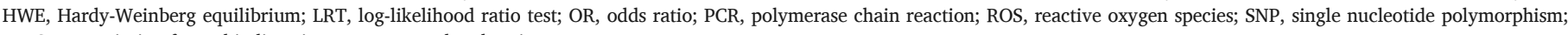
TFBS, transcription factor binding site; UTR, untranslated region.

* Corresponding author at: Department of Biology, Medical Genetics and Ecology, Kursk State Medical University, 3 Karl Marx St., Kursk 305041 , Russian Federation.

Email address: polonikov@rambler.ru (A. Polonikov) 
and collectively explained only a small fraction of the overall heritability (Hartiala et al., 2017), dictating the need of further investigation for understanding disease pathophysiology.

Alterations in the metabolism of arachidonic acid (AA) and other polyunsaturated fatty acids are known to be involved into the pathogenesis of CHD (Theken et al., 2012; Bellien and Joannides, 2013). Epoxyeicosatrienoic acids (EETs) are important vasoactive products of AA metabolism with a wide range of biological actions in the cardiovascular system (Bellien and Joannides, 2013; Spiecker and Liao, 2005; Seubert et al., 2007; Spector and Kim, 1851). Activating upon endogenous stimuli and oxidized by cytochrome P450 family 2 (CYP2) epoxygenases, EETs realize their cardiovascular effects through activating receptor-mediated signaling pathways and ion channels and possess vasodilatory, angiogenic and anti-inflammatory properties in the heart, vasculature and kidney (Spiecker and Liao, 2005; Spector and Kim, 1851; Fleming, 2001; Zordoky and El-Kadi, 2010). The CYP2 epoxygenases are found in the heart, vascular smooth muscle and endothelial cells where they are directly are involved in the biosynthesis of EETs from AA (Spiecker and Liao, 2005; Spector and Kim, 1851; Fleming, 2001; Zeldin, 2001).

Pursuing an interest in important cardiovascular functions of EETs, polymorphisms of genes encoding cytochrome P450 family 2 members became attractive candidates for genetic association studies of coronary heart disease (Lee et al., 2007; Ercan et al., 2008; Börgel et al., 2008; Marciante et al., 2008; Rothenbacher et al., 2013; Tang et al., 2016). Although some studies have revealed a relationship between genetic variants of CYP2 enzymes and CHD risk, nevertheless, most of them have yielded controversial results, showing that the pathogenetic role of these genes needs be clarified by independent studies. No studies have been done so far to investigate the contribution of genes encoding cytochrome P450 CYP2C subfamily to CHD susceptibility in Russians. Therefore, the purpose of this study was to investigate whether common single nucleotide polymorphisms (SNPs) of the CYP2C genes are associated with susceptibility to coronary heart disease in Russian population.

\section{Methods}

\subsection{Study participants}

Written informed consent was obtained from each study participant and the study protocol was approved by Ethical Review Committee of Kursk State Medical University. A total of 1255 unrelated Russian subjects comprising 561 patients with coronary heart disease and 694 healthy controls were included in this study. All patients with CHD were enrolled from Cardiology Divisions of Kursk Regional Clinical Hospital and Kursk Emergency Hospital as well as from Regional Cardiovascular Centre during a period between 2012 and 2015. All recruited patients had clinical signs or a history of CHD (angina or myocardial infarction) and angiographically confirmed narrowing of the coronary vessels by at least $50 \%$ in one or more major coronary artery. None of the enrolled CHD patients had signs and/or histories of congenital heart disease, cardiomyopathy, malignancy, connective-tissue disorder, chronic inflammatory disease, liver or kidney disease. The control group included blood donors, healthy volunteers as well as hospital-based patients recruited from surgical, traumatic, infectious divisions of Kursk hospitals without cardiovascular and other chronic diseases. The control group was recruited over several periods in the framework of our previous studies (Polonikov et al., 2007; Polonikov et al., 2008; Polonikov et al., 2009; Bushueva et al., 2014; Polonikov et al., 2015; Polonikov et al., 2017). Demographic and clinical characteristics of the study subjects are listed in Table 1 . As can be seen from Table 1, the group of CHD patients was matched to the control group on both sex and age $(P>0.05)$. A percentage of positive family history
Table 1

Demographic and clinical characteristics of the study patients.

\begin{tabular}{llll}
\hline Baseline characteristics & $\begin{array}{l}\text { Controls, } \\
\mathrm{n}=694\end{array}$ & $\begin{array}{l}\text { CAD } \\
\text { patients, } \\
\mathrm{n}=561\end{array}$ & $P$-value \\
\hline $\begin{array}{l}\text { Age, mean } \pm \text { standard } \\
\text { deviation }\end{array}$ & $60.8 \pm 9.0$ & $61.7 \pm 9.3$ & 0.08 \\
$\begin{array}{l}\text { Males, } \mathrm{n}(\%) \\
\text { Body mass index }\left(\mathrm{kg} / \mathrm{m}^{2}\right),\end{array}$ & $355(51.2)$ & $313(55.8)$ & 0.10 \\
$\begin{array}{l}\text { mean } \pm \text { standard deviation } \\
\text { Hypertension, } \mathrm{n}(\%)\end{array}$ & $27.9 \pm 7.4$ & $28.4 \pm 8.3$ & 0.26 \\
$\begin{array}{l}\text { Diabetes, } \mathrm{n}(\%) \\
\begin{array}{l}\text { Smokers (ever/never), } \mathrm{n} \\
\text { (\%) }\end{array}\end{array}$ & $0(0.0)$ & $455(89.2)$ & - \\
$\begin{array}{l}\text { Positive family history of } \\
\text { CHD, } \mathrm{n}(\%)\end{array}$ & $137(21.9)$ & $159(31.5)$ & $\mathbf{0 . 0 0 0 3}$ \\
$\begin{array}{l}\text { Positive family history of } \\
\text { hypertension, } \mathrm{n}(\%)\end{array}$ & $63(12.5)$ & $164(26.3)$ & $<\mathbf{0 . 0 0 0 1}$ \\
$\begin{array}{l}\text { Positive family history of } \\
\text { diabetes, } \mathrm{n}(\%)\end{array}$ & $23(3.7)$ & $75(14.8)$ & $<\mathbf{0 . 0 0 0 1}$ \\
\hline
\end{tabular}

Bolded is statistically significant $P$-value.

of CHD, hypertension, diabetes mellitus was significantly greater in the case group versus healthy controls. No differences were found between the groups regarding to other characteristics shown in Table 1.

\subsection{Selection of genes and SNPS}

Genes encoding CYP2C subfamily were selected on the basis of their involvement in the biosynthesis of EETs using information available at the KEGG PATHWAY (www.genome.jp/kegg/pathway.html), Reactome Pathway (www.reactome.org) and PharmGKB (www.pharmgkb. org) databases. Six common polymorphisms such as rs7909236, rs1934953 of CYP2C8, rs9332242, rs4918758 and rs61886769 of CYP2C9 and rs4244285 of CYP2C19 were selected based on their known functional relevance and/or haplotype tagging properties. The functionality of the SNPs was assessed in silico by the SNP Function Prediction tool developed by $\mathrm{Xu}$ and Taylor (Xu and Taylor, 2009) and available online at the SNPinfo Web Server (https://snpinfo.niehs. nih.gov/snpinfo/snpfunc.htm). Common SNPs such as rs11572103, rs11572080 and rs10509681 of CYP2C8 as well as rs1799853 and rs1057910 of CYP2C9 were not included in the study because they have not been confirmed to be associated with CHD risk by two independent studies (Kaur-Knudsen et al., 2009; Haschke-Becher et al., 2010). Among polymorphisms of the CYP2C19 gene, the only SNP rs4244285 was selected for our study because it is the most common variant associated with the formation of a dysfunctional protein (Desta et al., 2002).

\subsection{Genotyping}

Genomic DNA was extracted by standard phenol/chloroform procedure from whole blood samples obtained from all study participants. Polymerase Chain Reaction (PCR) was performed on the CFX96 Touch $^{\text {TM }}$ Real-Time PCR Detection System (Bio-Rad Laboratories, USA). SNP genotyping was performed using by the Mass-ARRAY 4 system (Agena Bioscience Inc., San Diego, CA, USA) at the Core Facility "Medical Genomics" in the Research Institute of Medical Genetics, Tomsk National Medical Research Center (Tomsk, Russia). Blind replicates were included for quality control.

\subsection{Data analysis}

An association analysis between SNPs and CHD risk could detect a difference of $4-7 \%$ in the genotype distributions between the cases and controls assuming 75-98\% statistical power and a 5\% type I error 
( $\alpha=0.05$ ) on the basis of the sample sizes of 561 CHD patients and 694 healthy controls. Allele frequencies were estimated by the gene counting method, and the chi-squire test was used to assess significant departures from Hardy-Weinberg equilibrium. Categorical variables were also compared by using the chi-squire test. Allele, genotype and haplotype frequencies in the study groups were evaluated by SNPStats, software which has been designed to analyze genetic associations using SNPs (Solé et al., 2006). The association between genotypes and CHD risk was measured by multiple logistic regression analysis to calculate odds ratios (OR) with 95\% confidence intervals (CI) and adjusted for age and gender at codominant genetic model. Statistical calculations were performed by using the SNPassoc package for R (González et al., 2007) and SNPStats software (Solé et al., 2006). Epistatic interactions between SNPs were analyzed by SNPassoc package for R using a log-likelihood ratio test (LRT) (González et al., 2007) and assuming codominant, dominant and recessive models. Haplotypes of CYP2C8 and CYP2C9 were estimated in entire groups of CHD patients and controls using by the SNPStats software. $P$-value $\leq 0.05$ was set to be statistically significant. As an adjustment for multiple testing, false discovery rate (FDR) based $Q$-value was calculated for each SNP using the method proposed by Benjamini and Hochberg (1995) and implemented in the FDR calculator available online at http://www.sdmproject.com/ utilities/?show = FDR. Significance of the associations was assessed by a 0.20 threshold of $Q$-value, as previously suggested (Smith et al., 2007).

The regulatory potential of the studied SNPs was evaluated by using the SNP Function Prediction tool (https://snpinfo.niehs.nih.gov/ snpinfo/snpfunc.php) (Xu and Taylor, 2009) utilizing an information of the TRANSFAC database on potential transcription factor recognition sites (BIOBASE Corporation, Wolfenbuettel, Germany). Only transcription factor binding sites (TFBS) whose core or matrix match score was impacted, or which were eliminated or created by variant sequences are considered to be regulatory within a particular SNP. The SNP Function Prediction tool was also utilized to scan the SNPs for the presence of potential binding sites for microRNAs (miRNAs). In addition,
rSNPBase, a database of curated regulatory SNPs (http://rsnp.psych.ac. cn) (Guo et al., 2014) and functional in vitro studies available from the literature were used to analyze and interpret genotype-phenotype relationships.

\section{Results}

\subsection{Association analysis between CYP2C gene subfamily and CHD risk}

Table 2 shows the genotype and allele frequencies of CYP2C polymorphisms. Allele and genotype frequencies were compatible with those reported in other European populations (the 1000 Genomes Project, http://www.internationalgenome.org). The genotype distribution for majority of SNPs was consistent with the population being in Hardy-Weinberg equilibrium, HWE $(P>0.05)$. A significant departure of genotype frequencies from HWE was found only for SNP rs4244285 of CYP2C19 $(P=0.02)$. As can be seen from Table 2, SNP rs 4918758 of CYP2C9 was associated with decreased risk of CHD at a borderline significance with odds ratio adjusted for sex and age 0.61 (95\% CI: $0.41-0.92, P=0.038, Q=0.20$ ). Gender-stratified analysis (Supplementary Table 1 ) revealed no differences in allele and genotype frequencies between the case and control groups in both males and females $(P>0.05)$.

\subsection{Interactions between SNPs of CYP2C gene subfamily and CHD risk}

Then log-likelihood ratio test was performed to look for epistatic interaction between SNPs that determine the susceptibility to CHD (Table 3). As can be seen from Table 3, SNP rs4918758 of CYP2C9 $(P=0.011), \quad$ rs9332242 of CYP2C9 $(P=0.039)$, rs4244285 of CYP2C19 $(P=0.031)$ showed the main effects on CHD risk (recessive genetic model), as determined by the LRT. In addition, the log-likelihood ratio test analysis identified epistatic interactions between rs9332242 and rs61886769 of CYP2C9 (codominant model, $P_{\text {interaction }}=0.02$ ). However, these $P$-values did not survive after correction for multiple tests.

Table 2

Genotype and allele frequencies for SNPs of the CYP2C gene family in CHD patients and healthy controls.

\begin{tabular}{|c|c|c|c|c|c|c|}
\hline Gene, polymorphism & Genotype, allele & $\begin{array}{l}\text { Controls, } \mathrm{n}=694 \\
\mathrm{n}(\%)^{\mathrm{a}}\end{array}$ & $\begin{array}{l}\text { CHD patients, } \mathrm{n}=561 \\
\mathrm{n}(\%)^{\mathrm{a}}\end{array}$ & OR $(95 \mathrm{CI})^{\mathrm{b}}$ & $P$-value & $Q$-value \\
\hline \multirow[t]{4}{*}{ CYP2C8, G > T (rs7909236) } & $\mathrm{G} / \mathrm{G}$ & $422(60.8)$ & $316(56.3)$ & 1.00 & 0.19 & 0.29 \\
\hline & $\mathrm{G} / \mathrm{T}$ & $239(34.4)$ & $210(37.4)$ & $1.19(0.94-1.50)$ & & \\
\hline & $\mathrm{T} / \mathrm{T}$ & $33(4.8)$ & $35(6.2)$ & $1.42(0.86-2.34)$ & & \\
\hline & $\mathrm{T}$ & $305(22.0)$ & $280(25.0)$ & $1.18(0.98-1.42)$ & 0.08 & 0.27 \\
\hline \multirow[t]{4}{*}{ CYP2C8, T > C (rs1934953) } & $\mathrm{T} / \mathrm{T}$ & $316(45.5)$ & 245 (43.7) & 1.00 & 0.56 & 0.67 \\
\hline & $\mathrm{T} / \mathrm{C}$ & $314(45.2)$ & 255 (45.5) & $1.04(0.82-1.32)$ & & \\
\hline & $\mathrm{C} / \mathrm{C}$ & $64(9.2)$ & $61(10.9)$ & $1.24(0.84-1.83)$ & & \\
\hline & $\mathrm{C}$ & $442(31.8)$ & $377(33.6)$ & $1.08(0.92-1.28)$ & 0.35 & 0.39 \\
\hline \multirow[t]{4}{*}{ CYP2C9, C > G (rs9332242) } & $\mathrm{C} / \mathrm{C}$ & $557(80.4)$ & $458(81.6)$ & 1.00 & 0.10 & 0.20 \\
\hline & $\mathrm{C} / \mathrm{G}$ & 124 (17.9) & $100(17.8)$ & $1.00(0.75-1.34)$ & & \\
\hline & $\mathrm{G} / \mathrm{G}$ & $12(1.7)$ & $3(0.5)$ & $0.29(0.08-1.02)$ & & \\
\hline & G & $148(10.7)$ & $106(9.4)$ & $0.87(0.67-1.14)$ & 0.31 & 0.39 \\
\hline \multirow[t]{4}{*}{ CYP2C9, T > C (rs4918758) } & $\mathrm{T} / \mathrm{T}$ & 310 (44.7) & $262(46.7)$ & 1.00 & 0.038 & 0.20 \\
\hline & $\mathrm{T} / \mathrm{C}$ & $302(43.5)$ & $257(45.8)$ & $1.01(0.80-1.28)$ & & \\
\hline & $\mathrm{C} / \mathrm{C}$ & $82(11.8)$ & $42(7.5)$ & $0.61(0.41-0.92)$ & & \\
\hline & $\mathrm{C}$ & $466(33.6)$ & $341(30.4)$ & $0.86(0.73-1.02)$ & 0.09 & 0.27 \\
\hline \multirow[t]{4}{*}{ CYP2C9, $\mathrm{T}>\mathrm{C}(\mathrm{rs} 61886769)$} & $\mathrm{T} / \mathrm{T}$ & $451(65)$ & $377(67.2)$ & 1.00 & 0.67 & 0.67 \\
\hline & $\mathrm{T} / \mathrm{C}$ & $220(31.7)$ & 168 (29.9) & $0.91(0.72-1.17)$ & & \\
\hline & $\mathrm{C} / \mathrm{C}$ & $23(3.3)$ & $16(2.8)$ & $0.81(0.42-1.57)$ & & \\
\hline & $\mathrm{C}$ & $266(19.2)$ & $200(17.8)$ & $0.91(0.75-1.12)$ & 0.39 & 0.39 \\
\hline \multirow[t]{4}{*}{ CYP2C19, G > A (rs4244285) } & $\mathrm{G} / \mathrm{G}$ & $543(78.2)$ & 448 (79.9) & 1.00 & 0.086 & 0.20 \\
\hline & $\mathrm{G} / \mathrm{A}$ & $130(18.7)$ & $106(18.9)$ & $1.00(0.75-1.33)$ & & \\
\hline & $\mathrm{A} / \mathrm{A}$ & $21(3)$ & $7(1.2)$ & $0.40(0.17-0.95)$ & & \\
\hline & A & $172(12.4)$ & $120(10.7)$ & $0.85(0.66-1.08)$ & 0.19 & 0.38 \\
\hline
\end{tabular}

a Absolute number and percentage of individuals/chromosomes with particular genotype/allele.

b Odds ratio with $95 \%$ confidence intervals adjusted for age and gender. 
Table 3

Epistatic interactions between CYP2C family gene polymorphisms in CHD (gene-gene interactions are evaluated by SNPassoc package for R (González et al., 2007)).

\begin{tabular}{|c|c|c|c|c|c|c|c|}
\hline SNPs & $\begin{array}{l}\text { Genetic } \\
\text { models }\end{array}$ & $\begin{array}{c}\text { CYP2C8 } \\
\text { (rs7909236) }\end{array}$ & $\begin{array}{c}\text { CYP2C8 } \\
(\mathrm{rs} 1934953)\end{array}$ & $\begin{array}{c}\text { CYP2C9 } \\
\text { (rs9332242) }\end{array}$ & $\begin{array}{c}\text { CYP2C9 } \\
\text { (rs4918758) }\end{array}$ & $\begin{array}{c}C Y P 2 C 9 \\
\text { (rs61886769) }\end{array}$ & $\begin{array}{c}\text { CYP2C19 } \\
\text { (rs4244285) }\end{array}$ \\
\hline \multirow{4}{*}{$\begin{array}{c}\text { CYP2C8 } \\
\text { (rs7909236) }\end{array}$} & Codominant & 0.192 & 0.324 & 0.148 & 0.363 & 0.841 & 0.314 \\
\hline & Dominant & 0.093 & 0.935 & 0.718 & 0.324 & 0.821 & 0.134 \\
\hline & Recessive & 0.251 & 0.589 & 0.161 & 0.171 & 0.311 & - \\
\hline & Overdominant & 0.238 & 0.223 & 0.513 & 0.369 & 0.893 & 0.109 \\
\hline \multirow{4}{*}{$\begin{array}{c}\text { CYP2C8 } \\
\text { (rs1934953) }\end{array}$} & Codominant & 0.690 & 0.564 & 0.202 & 0.552 & 0.797 & 0.309 \\
\hline & Dominant & 0.408 & 0.542 & 0.318 & 0.437 & 0.767 & 0.203 \\
\hline & Recessive & 0.727 & 0.307 & 0.183 & 0.226 & 0.785 & - \\
\hline & Overdominant & 0.344 & 0.995 & 0.137 & 0.740 & 0.451 & 0.156 \\
\hline \multirow{4}{*}{$\begin{array}{c}\text { CYP2C9 } \\
\text { (rs9332242) }\end{array}$} & Codominant & 0.180 & 0.533 & 0.120 & 0.209 & 0.020 & 0.772 \\
\hline & Dominant & 0.734 & 0.680 & 0.632 & 0.205 & 0.060 & 0.887 \\
\hline & Recessive & 0.195 & 0.274 & 0.039 & - & 0.560 & - \\
\hline & Overdominant & 0.884 & 0.979 & 0.926 & 0.595 & 0.067 & 0.687 \\
\hline \multirow{4}{*}{$\begin{array}{c}\text { CYP2C9 } \\
\text { (rs4918758) }\end{array}$} & Codominant & 0.246 & 0.659 & 0.349 & 0.041 & 0.211 & 0.724 \\
\hline & Dominant & 0.715 & 0.636 & 0.839 & 0.503 & 0.104 & 0.541 \\
\hline & Recessive & 0.259 & 0.378 & 0.168 & 0.011 & 0.281 & 0.305 \\
\hline & Overdominant & 0.336 & 0.982 & 0.879 & 0.398 & 0.257 & 0.380 \\
\hline \multirow{4}{*}{$\begin{array}{c}C Y P 2 C 9 \\
\text { (rs61886769) }\end{array}$} & Codominant & 0.756 & 0.731 & 0.541 & 0.570 & 0.670 & 0.287 \\
\hline & Dominant & 0.532 & 0.611 & 0.930 & 0.862 & 0.408 & 0.232 \\
\hline & Recessive & 0.559 & 0.577 & 0.435 & 0.328 & 0.591 & - \\
\hline & Overdominant & 0.594 & 0.973 & 0.553 & 0.179 & 0.518 & 0.126 \\
\hline \multirow{4}{*}{$\begin{array}{c}\text { CYP2C19 } \\
(\mathrm{rs} 4244285)\end{array}$} & Codominant & 0.270 & 0.652 & 0.092 & 0.437 & 0.535 & 0.099 \\
\hline & Dominant & 0.756 & 0.643 & 0.586 & 0.709 & 0.417 & 0.526 \\
\hline & Recessive & 0.286 & 0.361 & 0.030 & 0.215 & 0.550 & 0.031 \\
\hline & Overdominant & 0.762 & 0.989 & 0.919 & 0.891 & 0.950 & 0.879 \\
\hline
\end{tabular}

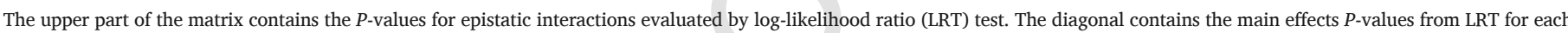

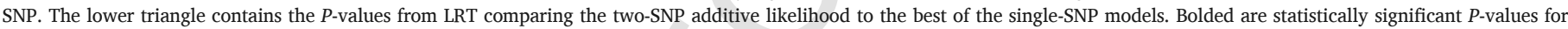
SNP-SNP interactions. $P$-values are adjusted for age and gender. All $P$-values are not adjusted for multiple tests.

\subsection{Analysis of haplotypes and linkage disequilibrium between SNPs}

The patterns of estimated haplotypes and their frequencies in the case and control groups are shown in Table 4. Three haplotypes of the CYP2C8 gene and four haplotypes of the CYP2C9 gene with a fre-

Table 4

Estimated haplotype frequencies in CHD patients and controls.

\begin{tabular}{|c|c|c|c|c|c|}
\hline & $e^{a}$ & Controls & $\begin{array}{l}\text { CHD } \\
\text { patients }\end{array}$ & OR $(95 \mathrm{CI})^{\mathrm{b}}$ & $\begin{array}{l}P \text { - } \\
\text { value }\end{array}$ \\
\hline \multicolumn{6}{|c|}{ SNPs G > T (rs7909236) and $\mathrm{T}>\mathrm{C}(\mathrm{rs} 1934953)$ of $C Y P 2 C 8$} \\
\hline 1 & G-T & 0.6735 & 0.6551 & 1.00 & - \\
\hline 2 & T-C & 0.2116 & 0.2407 & $\begin{array}{l}1.17 \\
(0.97-1.42)\end{array}$ & 0.11 \\
\hline 3 & G-C & 0.1068 & 0.0954 & $\begin{array}{l}0.92 \\
(0.70-1.20)\end{array}$ & 0.52 \\
\hline \multicolumn{6}{|c|}{ Global haplotype association $P$-value: 0.29} \\
\hline \multicolumn{6}{|c|}{ SNPs C > G (rs9332242), $\mathrm{T}>\mathrm{C}(\mathrm{rs} 4918758)$ and $\mathrm{T}>\mathrm{C}(\mathrm{rs} 61886769)$ of CYP2C9 } \\
\hline 1 & $\begin{array}{l}\text { C- } \\
\text { T-T }\end{array}$ & 0.6598 & 0.6941 & 1.00 & - \\
\hline 2 & $\begin{array}{l}\text { C- } \\
\text { C-T }\end{array}$ & 0.1431 & 0.1267 & $\begin{array}{l}0.85 \\
(0.67-1.07)\end{array}$ & 0.16 \\
\hline 3 & $\begin{array}{l}\text { G- } \\
\text { C-C }\end{array}$ & 0.1003 & 0.0935 & $\begin{array}{l}0.89 \\
(0.68-1.17)\end{array}$ & 0.40 \\
\hline 4 & $\begin{array}{l}\mathrm{C}- \\
\mathrm{C}-\mathrm{C}\end{array}$ & 0.0896 & 0.0837 & $\begin{array}{l}0.87 \\
(0.65-1.17)\end{array}$ & 0.36 \\
\hline & aploty & ciation $P$ - & 0.16 & & \\
\hline
\end{tabular}

a Rare haplotypes with frequency $<0.01$ are not shown.

b Odds ratio with $95 \%$ confidence intervals adjusted for age and gender. quency $>1 \%$ have been identified in the study patients. Haplotype frequencies of CYP2C8 and CYP2C9 were compared between CHD patients and controls using a chi-square test (Table 4). There was no significant difference in the haplotype distribution of CYP2C8 and CYP2C9 between the case and control groups $(P>0.05)$. Polymorphisms rs7909236 and rs1934953 of the CYP2C8 gene were in positive linkage disequilibrium $\left(\mathrm{D}^{\prime}=0.946, P<0.0001\right.$ ), indicating that the wild type allele at one site is more likely to be associated with the wild type allele at the other site. All three polymorphisms of CYP2C9 were in a strong linkage disequilibrium to each other $\left(\mathrm{D}^{\prime}=0.958-0.989, P<0.0001\right)$.

\subsection{Analysis of SNP-smoking interactions}

Table 5 shows the results of analysis for SNP-smoking interactions and their contribution to CHD risk at codominant genetic model. As can be seen from Table 5, SNP rs9332242 of CYP2C9 showed a trend towards association with increased risk of coronary heart disease in cigarette smokers $(P=0.049, Q=0.29)$. No SNP-smoking interactions were found for other polymorphisms.

\subsection{Bioinformatic analysis for regulatory potential of SNPS}

Results of bioinformatic analysis for the regulatory potential of the studied SNPs are shown in Table 6. The SNP Function Prediction tool allowed identifying putative transcription factor binding sites at SNPs rs7909236 of CYP2C8, rs4918758 and rs61886769 of CYP2C9 as well 
Table 5

SNP-smoking interactions and susceptibility to CHD.

\begin{tabular}{|c|c|c|c|c|c|c|c|c|}
\hline \multirow[t]{2}{*}{ Genotype } & \multicolumn{4}{|l|}{ Smokers } & \multicolumn{4}{|l|}{ Non-smokers } \\
\hline & $\begin{array}{l}\text { Controls, } \mathrm{n} \\
(\%)\end{array}$ & $\begin{array}{l}\text { CHD patients, } n \\
(\%)\end{array}$ & OR $(95 \% \mathrm{CI})^{\mathrm{a}}$ & $\begin{array}{l}P \text { - } \\
\text { value }\end{array}$ & $\begin{array}{l}\text { Controls, } \mathrm{n} \\
(\%)\end{array}$ & $\begin{array}{l}\text { CHD patients, } n \\
(\%)\end{array}$ & OR $(95 \% C I)^{a}$ & $\begin{array}{l}P \text { - } \\
\text { value }\end{array}$ \\
\hline \multicolumn{9}{|c|}{ SNP rs7909236 of $C Y P 2 C 8$} \\
\hline $\mathrm{G} / \mathrm{G}$ & $151(61.4)$ & 125 (61.9) & 1.00 & - & $256(60.2)$ & $165(52.1)$ & $\begin{array}{l}0.83 \\
(0.58-1.18)\end{array}$ & NS \\
\hline $\mathrm{G} / \mathrm{T}$ & $87(35.4)$ & $66(32.7)$ & $\begin{array}{l}0.93 \\
(0.62-1.39)\end{array}$ & NS & $145(34.1)$ & $131(41.3)$ & $\begin{array}{l}1.17 \\
(0.80-1.71)\end{array}$ & NS \\
\hline $\mathrm{T} / \mathrm{T}$ & $8(3.3)$ & $11(5.4)$ & $\begin{array}{l}1.69 \\
(0.66-4.34)\end{array}$ & NS & $24(5.6)$ & $21(6.6)$ & $\begin{array}{l}1.11 \\
(0.57-2.15)\end{array}$ & NS \\
\hline \multicolumn{9}{|c|}{ SNP $\times$ smoking interaction $P$-value: $0.21(Q$-value $=0.39)$} \\
\hline \multicolumn{9}{|c|}{ SNP rs1934953 of CYP2C8 } \\
\hline $\mathrm{T} / \mathrm{T}$ & $107(43.5)$ & $97(48.0)$ & 1.00 & - & $199(46.8)$ & $129(40.7)$ & $\begin{array}{l}0.75 \\
(0.51-1.12)\end{array}$ & NS \\
\hline $\mathrm{T} / \mathrm{C}$ & $118(48.0)$ & $89(44.1)$ & $\begin{array}{l}0.83 \\
(0.56-1.22)\end{array}$ & NS & $186(43.8)$ & $151(47.6)$ & $\begin{array}{l}0.94 \\
(0.64-1.39)\end{array}$ & NS \\
\hline $\mathrm{C} / \mathrm{C}$ & $21(8.5)$ & $16(7.9)$ & $\begin{array}{l}0.85 \\
(0.42-1.73)\end{array}$ & NS & $40(9.4)$ & $37(11.7)$ & $\begin{array}{l}1.07 \\
(0.61-1.85)\end{array}$ & NS \\
\hline \multicolumn{9}{|c|}{ SNP $\times$ smoking interaction $P$-value: $0.20(Q$-value $=0.39)$} \\
\hline \multicolumn{9}{|c|}{ SNP rs9332242 of CYP2C9 } \\
\hline $\mathrm{C} / \mathrm{C}$ & $204(82.9)$ & $155(76.7)$ & 1.00 & - & $333(78.5)$ & $267(84.2)$ & $\begin{array}{l}1.10 \\
(0.81-1.51)\end{array}$ & NS \\
\hline $\mathrm{C} / \mathrm{G}$ & $38(15.4)$ & $46(22.8)$ & $\begin{array}{l}1.61 \\
(1.00-2.60)\end{array}$ & 0.048 & $83(19.6)$ & 49 (15.5) & $\begin{array}{l}0.83 \\
(0.53-1.31)\end{array}$ & NS \\
\hline G/G & $4(1.6)$ & $1(0.5)$ & $\begin{array}{l}0.31 \\
(0.03-2.79)\end{array}$ & NS & $8(1.9)$ & $1(0.3)$ & $\begin{array}{l}0.17 \\
(0.02-1.35)\end{array}$ & NS \\
\hline \multicolumn{9}{|c|}{ SNP $\times$ smoking interaction $P$-value: $0.049(Q$-value $=0.29)$} \\
\hline \multicolumn{9}{|c|}{ SNP rs4918758 of CYP2C9 } \\
\hline $\mathrm{T} / \mathrm{T}$ & $111(45.1)$ & $87(43.1)$ & 1.00 & - & $189(44.5)$ & $154(48.6)$ & $\begin{array}{l}1.09 \\
(0.74-1.61)\end{array}$ & NS \\
\hline $\mathrm{T} / \mathrm{C}$ & 105 (42.7) & $100(49.5)$ & $\begin{array}{l}1.21 \\
(0.82-1.80)\end{array}$ & NS & $187(44.0)$ & $139(43.8)$ & $\begin{array}{l}1.00 \\
(0.67-1.49)\end{array}$ & NS \\
\hline $\mathrm{C} / \mathrm{C}$ & $30(12.2)$ & $15(7.4)$ & $\begin{array}{l}0.62 \\
(0.32-1.23)\end{array}$ & NS & 49 (11.5) & $24(7.6)$ & $\begin{array}{l}0.67 \\
(0.37-1.21)\end{array}$ & NS \\
\hline \multicolumn{9}{|c|}{ SNP $\times$ smoking interaction $P$-value: $0.52(Q$-value $=0.62)$} \\
\hline $\mathrm{T} / \mathrm{T}$ & $160(65.0)$ & $126(62.4)$ & 1.00 & & $275(64.7)$ & $225(71.0)$ & $\begin{array}{l}1.09 \\
(0.78-1.54)\end{array}$ & NS \\
\hline $\mathrm{T} / \mathrm{C}$ & $78(31.7)$ & $68(33.7)$ & $\begin{array}{l}1.10 \\
(0.74-1.64)\end{array}$ & NS & $135(31.8)$ & $85(26.8)$ & $\begin{array}{l}0.85 \\
(0.57-1.26)\end{array}$ & NS \\
\hline $\mathrm{C} / \mathrm{C}$ & $8(3.3)$ & $8(4.0)$ & $\begin{array}{l}1.22 \\
(0.45-3.36)\end{array}$ & NS & $15(3.5)$ & $7(2.2)$ & $\begin{array}{l}0.63 \\
(0.24-1.61)\end{array}$ & NS \\
\hline \multicolumn{9}{|c|}{ SNP $\times$ smoking interaction $P$-value: $0.26(Q$-value $=0.39)$} \\
\hline \multicolumn{9}{|c|}{ SNP rs 4244285 of $C Y P 2 C 19$} \\
\hline $\mathrm{G} / \mathrm{G}$ & $192(78.0)$ & $162(80.2)$ & 1.00 & - & $336(79.1)$ & $248(78.2)$ & $\begin{array}{l}0.92 \\
(0.67-1.27)\end{array}$ & NS \\
\hline $\mathrm{G} / \mathrm{A}$ & $47(19.1)$ & $38(18.8)$ & $\begin{array}{l}0.95 \\
(0.59-1.53)\end{array}$ & NS & $76(17.9)$ & $64(20.2)$ & $\begin{array}{l}1.07 \\
(0.70-1.65)\end{array}$ & NS \\
\hline $\mathrm{A} / \mathrm{A}$ & $7(2.8)$ & $2(1.0)$ & $\begin{array}{l}0.34 \\
(0.07-1.66)\end{array}$ & NS & $13(3.1)$ & $5(1.6)$ & $\begin{array}{l}0.47 \\
(0.16-1.36)\end{array}$ & NS \\
\hline
\end{tabular}

NS means non-significant.

a Odds ratio with $95 \%$ confidence intervals adjusted for age and gender (codominant genetic model).

as microRNA-binding sites and/or RNA binding protein mediated regulation sites at SNPs rs1934953 of CYP2C8, rs9332242 of CYP2C9 and rs4244285 of CYP2C19. The lists of TFBS (rs4918758 and rs61886769 of CYP2C9, rs7909236 of CYP2C8) and microRNA-binding sites (rs9332242 of CYP2C9) are presented in Supplementary Tables 2-4 and 5 , respectively.

\section{Discussion}

\subsection{Summary of the study findings}

To our knowledge, this is the first study investigated the contribution of SNPs rs7909236, rs1934953 of CYP2C8 and rs9332242, rs4918758, rs61886769 of CYP2C9 to the risk of coronary heart disease. We found that SNP rs4918758 of the CYP2C9 gene is associated with decreased risk of CHD. The log-likelihood ratio test showed that SNP rs4918758 of CYP2C9, rs9332242 of CYP2C9, rs4244285 of
CYP2C19 have the main effects on CHD risk, and epistatic interactions between rs9332242 and rs61886769 of CYP2C9 contribute to disease susceptibility. Moreover, SNP rs9332242 of CYP2C9 showed a suggestive association with increased risk of coronary heart disease in cigarette smokers $(P=0.049, Q=0.29)$. Bioinformatic analysis revealed the functionality of the studied SNPs: the presence of multiple putative TFBS at SNPs rs7909236 of CYP2C8, rs4918758 and rs61886769 of CYP2C9 as well as microRNA-binding sites and/or RNA binding protein mediated regulation sites at SNPs rs1934953 of CYP2C8, rs9332242 of CYP2C9 and rs4244285 of CYP2C19.

\subsection{Pathogenetic relationship between SNPs and coronary heart disease}

A literature search identified a few studies investigated the role of the CYP2C gene subfamily in the development of coronary heart disease (Lee et al., 2007; Ercan et al., 2008; Marciante et al., 2008; Rothenbacher et al., 2013). Numerous studies considered the studied 
Table 6

Bioinformatic analysis for the regulatory potential of the studied SNPs in patients with coronary heart disease and healthy subjects.

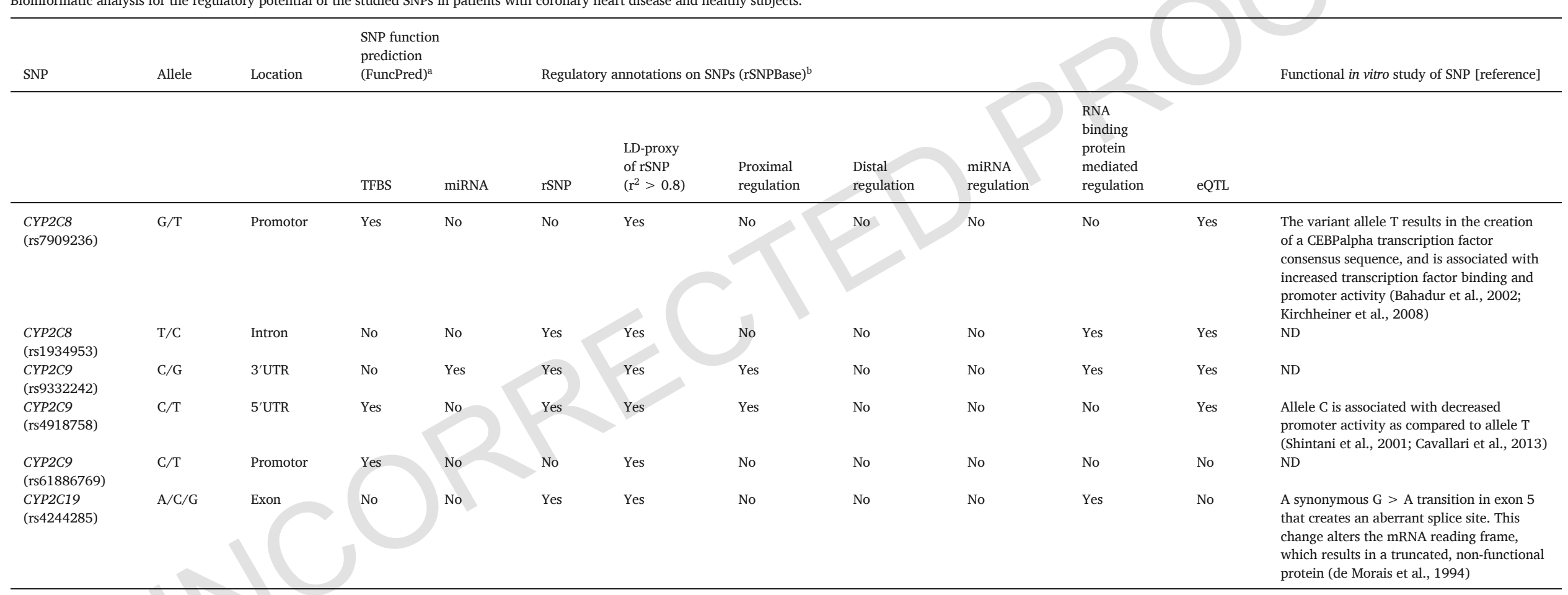

Data predicted by the SNP Function Prediction tool, National Institute of Environmental Health Sciences (https://snpinfo.niehs.nih.gov/snpinfo/snpfunc.php): TFBS, transcription factor binding site; ND, no data

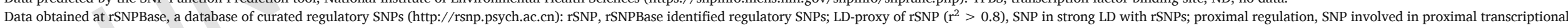

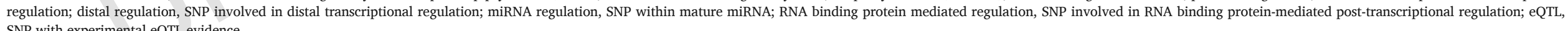
SNP with experimental eQTL evidence. 
genes as candidates for pharmacogenetic investigations of drugs (Hirota et al., 2013; Backman et al., 2016). Ercan with co-workers investigated SNPs rs1799853 (CYP2C9*2), rs1057910 (CYP2C9*3) and rs4986893 $(C Y P 2 C 19 * 3)$ and found that cigarette smokers with heterozygote genotype for CYP2C9*2 had 3.7-fold risk of developing coronary heart disease (Ercan et al., 2008). Additionally, the CYP2C19*3 variant (SNP rs4986893 or rs57081121) was found to associated with a three-fold risk of coronary atherosclerosis (Ercan et al., 2008). Excepting participation in biosynthesis of EETs, CYP2C19 is also involved in the metabolism of a number of drugs such as platelet aggregation antagonists, proton pump inhibitors, anti-diabetes and anti-cancer drugs (Wei et al., 2008). SNP rs4244285 of CYP2C19 (CYP2C19*2 allele) represents a synonymous $681 \mathrm{G}>\mathrm{A}$ transition in exon 5 that creates an aberrant splice site altering the mRNA reading frame and resulting in a truncated non-functional protein (de Morais et al., 1994). An apparent protective effect of this SNP against CHD risk observed in our study can be interpreted by that the loss-of-function variant of CYP2C19 is related with decreased enzyme activity and therefore decreased production of reactive oxygen species (ROS) by this cytochrome P450. Notably, the similar protective effect of the CYP2C19*2 variant was noted against the risk of tuberculosis (Backman et al., 2016). Meantime, our finding is inconsistent with the study results of Rothenbacher et al. (2013) who revealed that patients with stable CHD and homozygous for the CYP2C19*2 loss-of-function gene have an increased risk for subsequent myocardial infarction during 8 year follow-up. This means that functional studies on this SNP are required to clarify this inconsistence.

We found that SNP rs4918758 may possess a protective effect against the CHD risk. Comparing the SNPs constituting each promoter variants of CYP2C9 against the variants located within putative TFBS, only two polymorphisms rs4918758 and rs61886769 were found to be located within potential recognition sites for numerous transcription factors. In particular, transcription factors CDPCR3, FAC1, LUN1, OCT1, PPARA, SOX9 and Tal-1beta:E47 have been identified to co-regulate the promoter activity of CYP2C9 (see Supplementary Tables 2 and 3). These TFBSs were highlighted because they reduced or increased significantly matrix match score by the variant allele, as reported in accordance with the TRANSFAC database. It is known from the literature that allele $\mathrm{C}$ is associated with decreased promoter activity as compared to allele $\mathrm{T}$ (Shintani et al., 2001; Cavallari et al., 2013). Hence, homozygous genotype CC may be related with decreased risk of CHD because a decreased promoter activity of CYP2C9 in such individuals is capable to enhance ROS production and formation of oxidative stress, an important mechanism of atherosclerosis (Kondo et al., 2009; Li et al., 2014).

\subsection{SNP rs9332242-smoking interaction and CHD risk}

Lee with co-workers (Lee et al., 2007) observed that cigarette smoking may modify the relationship between common polymorphisms I264M (rs1058930) and K399R (rs10509681) of CYP2C8 related with decreased enzyme activity (Gao et al., 2010) and the risk of CHD. An interesting finding of our study was a suggestive association between SNP rs9332242 of CYP2C9 and CHD risk in cigarette smokers. No functional in vitro studies were undertaken to analyze the relationship between polymorphism rs9332242 and expression levels of CYP2C9. We cannot exclude that the functional effect of SNP rs9332242 can be explained by linkage disequilibrium with other SNPs: at least 58 SNPs are being in LD with rs9332242 $\left(\mathrm{r}^{2}>0.8\right)$ in accordance with the rSNPBase database (http://rsnp.psych.ac.cn/snp.do?snp=rs9332242). The SNP Function Prediction tool allowed identifying TFBS and microRNA-binding sites located at the rs9332242 polymorphism. In particular, we found that SNP rs9332242 CYP2C9 is located within binding sites for miRNAs such as miR-1321, miR-143, miR-216a, miR-299-3p, miR-552 and miR-595 as well as within recognition sequences for numerous putative TFBSs (see Supplementary Table 5). miRNAs are short non-coding RNAs involved in post-transcriptional regulation of gene expression most commonly resulting in translational inhibition or destabilization of the target mRNA. In the light of interpretation of the SNP-smoking interaction, miR-143 and miR-299-3p attract significant attention with respect to a potential dependence of their expression on smoking exposure. SNP rs9332242 is located at $3^{\prime}$ untranslated region (UTR) of the CYP2C9 gene within miRNA binding site for miR-143 which was known to be strongly up-regulated in tobacco smokers (Wang et al., 2015). It is also known that smoking may cause significant changes in the expression of miR-299-3p whose binding site comprises SNP rs9332242 (Guled et al., 2009). In addition, the study of Ercan with co-workers observed a synergic effect of tobacco smoking and SNP rs1799853 on the risk of coronary atherosclerosis (Ercan et al., 2008). Taken together these data point out that SNPs located within miRNA target sites (e.g. rs9332242 and rs1799853) may play a pivotal role in the pathogenesis of smoking-related diseases as miRNAs bind to 3 ' UTR regions of genes, thereby regulating their expression (Momi et al., 2014). It is important to note that miR-552, another miRNA binding site located at rs9332242, possesses a dual inhibitory ability on the target genes at transcriptional and post-transcriptional levels. This feature was demonstrated by the study with effective inhibition of the CYP2E1 gene (Miao et al., 2016) which, like CYP2C9, is also involved in the formation of EETs from arachidonic acid (Rifkind et al., 1995). Further studying polymorphism rs9332242 of CYP2C9 and associated miRNAs in conjunction with the intermodulation between them upon smoking exposure may help to provide mechanistic insights into the mechanism by which the locus influences the risk of coronary heart disease in cigarette smokers. On the one hand, the synergic effect of smoking exposure and genotype $\mathrm{C} / \mathrm{G}$ (rs9332242) points out that the $\mathrm{G}$ variant increases the activity of CYP2C9 enzyme potentiating a pro-oxidant action of cigarette smoke through enhanced generation of ROS, oxidative stress and vascular inflammation. On the other hand, loss-of-function effect of this SNP may be responsible for a deficiency of EETs which are known to be involved in endothelium-dependent vasodilation, endothelial survival via cytoprotective functions, thereby preventing apoptotic and oxidative vascular injury (Spiecker and Liao, 2005; Fleming, 2001). In any case, further studies are required to analyze the functional effects of the studied SNPs and to confirm our suggestions.

\subsection{Study limitations}

The results of this study should be interpreted in the context of some limitations. The associations of the CYP2C9 polymorphisms with CHD risk were weak, sometimes even suggestive, demonstrating the discovery nature of our study. The study findings do not allow us to draw definitive conclusion on a comprehensive contribution of the studied genes to the development of coronary heart disease. We investigated a limited number of SNPs of CYP2C gene subfamily. Because of an insufficient number of patients in the study groups, we did not perform gene-smoking interaction analysis stratified by gender with an appropriate statistical power. Hence, the results of our study should be considered as preliminary and further investigation in larger population-based samples is required to address issues discussed above.

\section{Conclusion and perspective}

Nevertheless, the present study points out the polymorphisms of CYP2C9 could be potential genetic markers of susceptibility to coronary heart disease. The relationship between polymorphisms of $C Y P 2 C 9$ gene and CHD risk also demonstrates an importance of epoxygenase pathway of arachidonic acid metabolism for disease pathogenesis. Better understanding the relationships between altered CYP2C9 gene expression and function in patients with coronary heart disease 
may provide novel insights into disease pathophysiology and suggest specific targeted interventions that may expand the therapeutic options for cardiovascular disease in the future.

\section{Author contributions disclosure}

All authors provided critical review of the manuscript. A.P. and M.S.: designed the study, designed and carried out the statistical/bioinformatic analysis and wrote the manuscript; A.K.: clinical data collection and analysis, disease diagnosis; M.B.: DNA extraction, performed genotyping; S.S.: DNA extraction, performed genotyping; I.P.: DNA extraction, performed genotyping; A.B.: carried out the quality control of the data; K.V.: carried out the quality control of the data; V.S.: database creation, statistical analysis; O.B.: biological data collection and processing; M.C.: study phenotyping, data analysis.

\section{Uncited references}

Feng et al., 2012

Spiecker et al., 2004

\section{Acknowledgements}

\section{Appendix A. Supplementary data}

Supplementary data to this article can be found online at http://dx. doi.org/10.1016/j.gene.2017.07.004.

\section{References}

Arnett, D.K., Baird, A.E., Barkley, R.A., Basson, C.T., Boerwinkle, E., Ganesh, S.K., Herrington, D.M., Hong, Y., Jaquish, C., DA, McDermott, O'Donnell, C .J., American Heart Association Council on Epidemiology and Prevention, American Heart Association Stroke Council, Functional Genomics and Translational Biology Interdisciplinary Working Group, 2007. Relevance of genetics and genomics for prevention and treatment of cardiovascular disease: a scientific statement from the American Heart Association Council on Epidemiology and Prevention, the Stroke Council, and the Functional Genomics and Translational Biology Interdisciplinary Working Group. Circulation 115 (22), 2878-2901.

Backman, J.T., Filppula, A.M., Niemi, M., Neuvonen, P.J., 2016. Role of cytochrome P450 2C8 in drug metabolism and interactions. Pharmacol. Rev. 68 (1), 168-241. Bahadur,

N., Leathart, J.B., Mutch, E., Steimel-Crespi, D., Dunn, S.A., Gilissen, R., Houdt, J.V., Hendrickx, J., Mannens, G., Bohets, H., Williams, F.M., Armstrong, M., Crespi, C.L., Daly, A.K., 2002. CYP2C8 polymorphisms in Caucasians and their relationship with paclitaxel 6alpha-hydroxylase activity in human liver microsomes. Biochem. Pharmacol. 64 (11), 1579-1589.

Bellien, J., Joannides, R., 2013. Epoxyeicosatrienoic acid pathway in human health and diseases. J. Cardiovasc. Pharmacol. 61, 188-196.

Benjamini, Y., Hochberg, Y., 1995. Controlling the false discovery rate: a practical and powerful approach to multiple testing. J. R. Stat. Soc. B. 57, 289-300.

Börgel, J., Bulut, D., Hanefeld, C., Neubauer, H., Mügge, A., Epplen, J.T., Holland-Letz, T., Spiecker, M., 2008. The CYP2J2 G-50T polymorphism and myocardial infarction in patients with cardiovascular risk profile. BMC Cardiovasc. Disord. 8, 41.

Bushueva, O., Solodilova, M., C hurnosov, M., Ivanov, V., Polonikov, A., 2014. The flavin-containing monooxygenase 3 gene and essential hypertension: the joint effect of polymorphism E158K and cigarette smoking on disease susceptibility. Int. J. Hypertens. 2014, 712169.

Cavallari, L.H., Vaynshteyn, D., Freeman, K.M., Wang, D., Perera, M.A., Takahashi, H., Drozda, K., Patel, S.R., Jeong, H., 2013. CYP2C9 promoter region single-nucleotide polymorphisms linked to the $\mathrm{R} 150 \mathrm{H}$ polymorphism are functional suggesting their role in CYP2C9*8-mediated effects. Pharmacogenet. Genomics 23 (4), 228-231.

Desta, Z., Zhao, X., Shin, J.G., et al., 2002. Clinical significance of the cytochrome P450 2C19 genetic polymorphism. Clin. Pharmacokinet. 41, 913-958.

Ercan, B., Ayaz, L., Ciçek, D., Tamer, L., 2008. Role of CYP2C9 and CYP2C19 polymorphisms in patients with atherosclerosis. Cell Biochem. Funct. 26 (3), 309313.

Feng, W.X., Liu, F., Gu, Y., Jiao, W.W., Sun, L., Xiao, J., Wu, X.R., Miao, Q., Shen, C., Shen, D., Shen, A., 2012. Functional polymorphisms in CYP2C19 \& CYP3A5 genes associated with decreased susceptibility for paediatric tuberculosis. Indian J. Med. Res. 135 (5), 642-649.

Fleming, I., 2001. Cytochrome p450 and vascular homeostasis. Circ. Res. 89 (9), 753-762.

Gao, Y., Liu, D., Wang, H., Zhu, J., Chen, C., 2010. Functional characterization of five CYP2C8 variants and prediction of CYP2C8 genotype-dependent effects on in vitro and in vivo drug-drug interactions. Xenobiotica 40 (7), 467-475.

González, J.R., Armengol, L., Solé, X., Guinó, E., Mercader, J.M., Estivill, X., Moreno, V., 2007. SNPassoc: an $\mathrm{R}$ package to perform whole genome association studies. Bioinfor-matics 23 (5), 644-645.
Guled, M., Lahti, L., Lindholm, P.M., Salmenkivi, K., Bagwan, I., Nicholson, A.G., Knuutila, S., 2009. CDKN2A, NF2, and JUN are dysregulated among other genes by miRNAs in malignant mesothelioma - a miRNA microarray analysis. Genes Chromosom. Cancer 48 (7), 615-623.

Guo, L., Du, Y., Chang, S., Zhang, K., Wang, J., 2014. rSNPBase: a database for curated regulatory SNPs. Nucleic Acids Res. 42 (Database issue), D1033-D1039.

Hartiala, J., Schwartzman, W.S., Gabbay, J., Ghazalpour, A., Bennett, B.J., Allayee, H., 2017. The genetic architecture of coronary artery disease: current knowledge and future opportunities. C urr Atheroscler Rep 19 (2), 6. http://dx.doi.org/10.1007/ s11883-017-0641-6.

Haschke-Becher, E., Kirchheiner, J., Trummer, O., Grünbacher, G., Kainz, A., Boehm, B.O., März, W., Renner, W., 2010. Impact of CYP2C8 and 2C9 polymorphisms on coronary artery disease and myocardial infarction in the LURIC cohort. Pharmacogenomics 11 (10), 1359-1365.

Hirota, T., Eguchi, S., Ieiri, I., 2013. Impact of genetic polymorphisms in C YP2C9 and CYP2C19 on the pharmacokinetics of clinically used drugs. Drug Metab. Pharmacokinet. 28 (1), 28-37.

Kaur-Knudsen, D., Bojesen, S.E., Nordestgaard, B.G., 2009. Common polymorphisms in CYP2C9, subclinical atherosclerosis and risk of ischemic vascular disease in 52,000 individuals. Pharm. J. 9 (5), 327-332.

Kirchheiner, J., Meineke, I., Fuhr, U., Rodríguez-Antona, C., Lebedeva, E., Brockmöller, J., 2008. Impact of genetic polymorphisms in CYP2C8 and rosiglitazone intake on the urinary excretion of dihydroxyeicosatrienoic acids. Pharmacogenomics 9 (3), 277-288.

Kondo, T., Hirose, M., Kageyama, K., 2009. Roles of oxidative stress and redox regulation in atherosclerosis. J. Atheroscler. Thromb. 16 (5), 532-538.

Kontsevaya, A., Kalinina, A., Oganov, R., 2013. Econcomic burden of cardiovascular diseases in the Russian Federation. Value Health Reg. Issues 2, 199-204.

Lee, C.R., North, K.E., Bray, M.S., Couper, D.J., Heiss, G., Zeldin, D.C., 2007. CYP2J2 and CYP2C8 polymorphisms and coronary heart disease risk: the Atherosclerosis Risk in Communities (ARIC) study. Pharmacogenet. Genomics 17 (5), 349-358.

Li, H., Horke, S., Förstermann, U., 2014. Vascular oxidative stress, nitric oxide and atherosclerosis. Atherosclerosis 237 (1), 208-219.

Marciante, K.D., Totah, R.A., Heckbert, S.R., et al., 2008. C ommon variation in cytochrome $\mathrm{P} 450$ epoxygenase genes and the risk of incident nonfatal myocardial infarction and ischemic stroke. Pharmacogenet. Genomics 18 (6), 535-543.

McPherson, R., Tybjaerg-Hansen, A., 2016. Genetics of coronary artery disease. Circ. Res. 118 (4), 564-578.

Miao, L., Yao, H., Li, C., Pu, M., Yao, X., Yang, H., Qi, X., Ren, J., Wang, Y., 2016. A dual inhibition: microRNA-552 suppresses both transcription and translation of cytochrome P450 2E1. Biochim. Biophys. Acta 1859 (4), 650-662.

Momi, N., Kaur, S., Rachagani, S., Ganti, A.K., Batra, S.K., 2014. Smoking and microRNA dysregulation: a cancerous combination. Trends Mol. Med. 20 (1), 36-47.

de Morais, S.M., Wilkinson, G.R., Blaisdell, J., Nakamura, K., Meyer, U.A., Goldstein, J.A., 1994. The major genetic defect responsible for the polymorphism of S-mephenytoin metabolism in humans. J. Biol. Chem. 269 (22), 15419-15422.

Nikpay, M., Goel, A., Won, H.H., Hall, L.M., Willenborg, C., Kanoni, S., Saleheen, D., Kyriakou, T., Nelson, C.P., Hopewell, J.C., Webb, T.R., Zeng, L., Dehghan, A., Alver, M., Armasu, S.M., Auro, K., Bjonnes, A., Chasman, D.I., Chen, S., Ford, I., Frances-chini, N., Gieger, C., Grace, C., Gustafsson, S., Huang, J., Hwang, S.J., Kim, Y.K., Kle-ber, M.E., Lau, K.W., Lu, X., Lu, Y., Lyytikäinen, L.P., Mihailov, E., Morrison, A.C., Pervjakova, N., Qu, L., Rose, L.M., Salfati, E., Saxena, R., Scholz, M., Smith, A.V., Tikkanen, E., Uitterlinden, A., Yang, X., Zhang, W., Zhao, W., de Andrade, M., de Vries, P.S., van Zuydam, N.R., Anand, S.S., Bertram, L., Beutner, F., Dedoussis, G., Frossard, P., Gauguier, D., Goodall, A.H., Gottesman, O., Haber, M., Han, B.G., Huang, J., Jalilzadeh, S., Kessler, T., König, I.R., Lannfelt, L., Lieb, W., Lind, L., Lindgren, C.M., Lokki, M.L., Magnusson, P.K., Mallick, N.H., Mehra, N., Meitinger, T., Memon, F.U., Morris, A.P., Nieminen, M.S., Pedersen, N.L., Peters, A., Rallidis, L.S., Rasheed, A., Samuel, M., Shah, S.H., Sinisalo, J., Stirrups, K.E., Trompet, S., Wang, L., Zaman, K.S., Ardissino, D., Boerwinkle, E., Borecki, I.B., Bottinger, E.P., Buring, J.E., Chambers, J.C., Collins, R., Cupples, L.A., Danesh, J., Demuth, I., Elosua, R., Epstein, S.E., Esko, T., Feitosa, M.F., Franco, O.H., Franzosi, M.G., Granger, C.B., Gu, D., Gudnason, V., Hall, A.S., Hamsten, A., Harris, T.B., Hazen, S.L., Hengstenberg, C., Hofman, A., In-gelsson, E., Iribarren, C., Jukema, J.W., Karhunen, P.J., Kim, B.J., Kooner, J.S., Kullo, I.J., Lehtimäki, T., Loos, R.J., Melander, O., Metspalu, A., März, W., Palmer, C.N., Per-ola, M., Quertermous, T., Rader, D.J., Ridker, P.M., Ripatti, S., Roberts, R., Salomaa, V., Sanghera, D.K., Schwartz, S.M., Seedorf, U., Stewart, A.F., Stott, D.J., Thiery, J., Zalloua, P.A., O'Donnell, C.J., Reilly, M.P., Assimes, T.L., Thompson, J.R., Erdmann, J., Clarke, R. Watkins, H., Kathiresan, S., McPherson, R., Deloukas, P., Schunkert, H., Samani, N.J., Farrall, M., CARDIoGRAMplusC4D Consortium, 2015. A comprehensive 1,000 genomes-based genome-wide association meta-analysis of coronary artery disease. Nat. Genet. 47 (10), 1121-1130.

Notzon, F., Komarov, Y., Ermakov, S., Sempos, C., Marks, J., Sempos, E., 1998. Causes of declining life expectancy in Russia. JAMA 279, 793-800.

Polonikov, A.V., Ivanov, V.P., Belugin, D.A., Khoroshaya, I.V., Kolchanova, I.O. Solodilova, M.A., Tutochkina, M.P., Stepchenko, A.A., 2007. Analysis of common transforming growth factor beta-1 gene polymorphisms in gastric and duodenal ulcer disease: pilot study. J. Gastroenterol. Hepatol. 22 (4), 555-564.

Polonikov, A.V., Ivanov, V.P., Solodilova, M.A., Khoroshaya, I.V., Kozhuhov, M.A., Ivakin, V.E., Katargina, L.N., Kolesnikova, O.E., 2008. A common polymorphism G-50T in cytochrome P450 2J2 gene is associated with increased risk of essential hypertension in a Russian population. Dis. Markers 24 (2), 119-126.

Polonikov, A.V., Ivanov, V.P., Solodilova, M.A., 2009. Genetic variation of genes for xenobiotic-metabolizing enzymes and risk of bronchial asthma: the importance of gene-gene and gene-environment interactions for disease susceptibility. J. Hum. Genet. 54 (8), 440-449. 
Polonikov, A.V., Ushachev, D.V., Ivanov, V.P., Churnosov, M.I., Freidin, M.B., Ataman, A.V., Harbuzova, V.Y., Bykanova, M.A., Bushueva, O.Y., Solodilova, M.A., 2015. Altered erythrocyte membrane protein composition mirrors pleiotropic effects of hypertension susceptibility genes and disease pathogenesis. J. Hypertens. 33 (11), 2265-2277.

Polonikov, A.V., Bushueva, O.Y., Bulgakova, I.V., Freidin, M.B., Churnosov, M.I., Solodilova, M.A., Shvetsov, Y.D., Ivanov, V.P., 2017. A comprehensive contribution of genes for aryl hydrocarbon receptor signaling pathway to hypertension susceptibility. Pharmacogenet. Genomics 27 (2), 57-69.

Poulter, N., 1999. Coronary heart disease is a multifactorial disease. Am. J. Hypertens. 12 (10 Pt 2), 92S-95S.

Rifkind, A.B., Lee, C., Chang, T.K., Waxman, D.J., 1995. Arachidonic acid metabolism by human cytochrome P450s 2C8, 2C9, 2E1, and 1A2: regioselective oxygenation and evidence for a role for CYP2C enzymes in arachidonic acid epoxygenation in human liver microsomes. Arch. Biochem. Biophys. 320 (2), 380-389.

Roger, V.L., Go, A.S., Lloyd-Jones, D.M., Benjamin, E.J., Berry, J.D., Borden, W.B., Bravata, D.M., Dai, S., Ford, E.S., Fox, C.S., Fullerton, H.J., Gillespie, C., Hailpern, S.M., Heit, J.A., Howard, V.J., Kissela, B.M., Kittner, S.J., Lackland, D.T., Lichtman, J.H., Lisabeth, L.D., Makuc, D.M., Marcus, G.M., Marelli, A., Matchar, D.B., Moy, C.S., Mozaffarian, D., Mussolino, M.E., Nichol, G., Paynter, N.P., Soliman, E.Z., Sorlie, P.D., Sotoodehnia, N., Turan, T.N., Virani, S.S., Wong, N.D., Woo, D., Turner, M.B., American Heart Association Statistics Committee and Stroke Statistics Subcommittee, 2012. Heart disease and stroke statistics_-2012 update: a report from the American Heart Association. Circulation 125 (1), e2-e220.

Rothenbacher, D., Hoffmann, M.M., Breitling, L.P., Rajman, I., Koenig, W., Brenner, H., 2013. Cytochrome P450 2C19*2 polymorphism in patients with stable coronary heart disease and risk for secondary cardiovascular disease events: results of a long-term follow-up study in routine clinical care. BMC Cardiovasc. Disord. 13, 61.

Seubert, J.M., Zeldin, D.C., Nithipatikom, K., Gross, G.J., 2007. Role of epoxyeicosatrienoic acids in protecting the myocardium following ischemia/reperfusion injury. Prostaglandins Other Lipid Mediators 82 (1-4), 50-59.

Shintani, M., Ieiri, I., Inoue, K., Mamiya, K., Ninomiya, H., Tashiro, N., Higuchi, S., Otsubo, K., 2001. Genetic polymorphisms and functional characterization of the $5^{\prime}$-flanking region of the human CYP2C9 gene: in vitro and in vivo studies. Clin. Pharmacol. Ther. 70 (2), 175-182.

Smith, N.L., Hindorff, L.A., Heckbert, S.R., Lemaitre, R.N., Marciante, K.D., Rice, K., Lumley, T., Bis, J.C., Wiggins, K.L., Rosendaal, F.R., Psaty, B.M., 2007. Association of ge- netic variations with nonfatal venous thrombosis in postmenopausal women. JAMA 297 (5), 489-498.

Solé, X., Guinó, E., Valls, J., Iniesta, R., Moreno, V., 2006. SNPStats: a web tool for the analysis of association studies. Bioinformatics 22 (15), 1928-1929.

Spector, A.A., Kim, H.Y., 1851. Cytochrome P450 epoxygenase pathway of polyunsaturated fatty acid metabolism. Biochim. Biophys. Acta 2015, 356-365.

Spiecker, M., Liao, J.K., 2005. Vascular protective effects of cytochrome p450 epoxygenase derived eicosanoids. Arch. Biochem. Biophys. 433 (2), 413-420.

Spiecker, M., Darius, H., Hankeln, T., Soufi, M., Sattler, A.M., Schaefer, J.R., Node, K., Börgel, J., Mügge, A., Lindpaintner, K., Huesing, A., Maisch, B., Zeldin, D.C., Liao, J.K., 2004. Risk of coronary artery disease associated with polymorphism of the cytochrome P450 epoxygenase CYP2J2. Circulation 110 (15), 2132-2136.

Tang, X.F., Han, Y.L., Zhang, J.H., Wang, J., Yao, Y., He, C., Xu, B., Gao, Z., Qiao, S.B., Chen, J., Wu, Y., Chen, J.L., Gao, R.L., Yang, Y.J., Yuan, J.Q., 2016. CYP2C19 genotyping combined with on-clopidogrel platelet reactivity in predicting major adverse cardiovascular events in Chinese patients with percutaneous coronary intervention. Thromb. Res. 147, 108-114.

Theken, K.N., Schuck, R.N., Edin, M.L., Tran, B., Ellis, K., Bass, A., Lih, F.B., Tomer, K.B., Poloyac, S.M., Wu, M.C., Hinderliter, A.L., Zeldin, D.C., Stouffer, G.A., Lee, C.R., 2012 Evaluation of cytochrome P450-derived eicosanoids in humans with stable atherosclerotic cardiovascular disease. Atherosclerosis 222, 530-536.

Wang, G., Wang, R., Strulovici-Barel, Y., Salit, J., Staudt, M.R., Ahmed, J., Tilley, A.E., Yee-Levin, J., Hollmann, C., Harvey, B.G., Kaner, R.J., Mezey, J.G., Sridhar, S., Pillai, S.G., Hilton, H., Wolff, G., Bitter, H., Visvanathan, S., Fine, J.S., Stevenson, C.S., Crystal, R.G., 2015. Persistence of smoking-induced dysregulation of miRNA expression in the small airway epithelium despite smoking cessation. PLoS One 10 (4), e0120824.

Wei, D.Q., Wang, J.F., Chen, C., et al., 2008. Molecular modeling of two CYP2C19 SNPs and its implications for personalized drug design. Protein Pept. Lett. 15 (1), 27-32.

Xu, Z., Taylor, J.A., 2009. SNPinfo: integrating GWAS and candidate gene information into functional SNP selection for genetic association studies. Nucleic Acids Res. 37 (Web Server issue), W600-W605.

Zeldin, D.C., 2001. Epoxygenase pathways of arachidonic acid metabolism. J. Biol. Chem. 276 (39), 36059-36062.

Zordoky, B.N., El-Kadi, A.O., 2010. Effect of cytochrome P450 polymorphism on arachidonic acid metabolism and their impact on cardiovascular diseases. Pharmacol. Ther. $125,446-463$. 